\title{
The Role of Private Actors in the Regulation and Enforcement of Corporate Environmental Harm
}

\author{
Judith van Erp*
}

\section{Introduction}

The beginning of the twenty-first century has been characterised by a profound change in relations between states and business as a result of globalisation, privatisation and financialisation. Globalisation has been enabled by the internationalisation of trade, the worldwide exchange of information, knowledge, labour and capital, and the dispersion of labour and human capital across the globe. Geographic distances and national borders have become less relevant with the growth of international trade and international relations, and the global economy is now more connected than ever. The density of relations, the velocity and scale of interactions, and the worldwide flows of capital and products, have created an open society, with greater opportunities for innovation, and more prosperity, welfare and freedom for many citizens across the globe. But the open society also generates new risks for citizens, as primary needs such as food, money, housing and energy, and communication and information, are now predominantly produced in globalised markets. More and more, citizens have come to depend on corporate actors operating in global networks. The open society not only creates opportunities beneficial to citizens, but also generates new and increased opportunities for corporate harmful behaviour, resulting in inequality, exploitation and sometimes disaster. The global financial crisis, various forms of corporate fraud such as the Volkswagen diesel fraud and the Libor affair, food hazards and manipulation, and massive environmental damage destroying ecosystems and local communities, have resulted from corporate irresponsible and unethical behaviour, straightforward corporate crimes and unforeseen effects of global system connectivity. The same mechanisms of globalisation that bring opportunities for growth and prosperity can also generate damage, insecurity and injustice for citizens.

\footnotetext{
* Judith van Erp is Professor of Public Institutions at Utrecht University, at the Utrecht School of Governance, and is a member of the Royal Dutch Academy of Sciences.
} 
This chapter asks how citizens can be effectively protected against risks resulting from corporate crime and corporate harmful behaviour in an open society. Following the example of scholarship on corporate crime, ${ }^{1}$ we use the term 'corporate crime and harm' to encompass not only illegal behaviours, but also the broad category of semi-legal, irresponsible and unethical corporate behaviours in unregulated or poorly regulated spaces (geographically and virtually), in which state enforcement is impossible and behaviour is 'lawful, but awful'. ${ }^{2}$ This chapter focuses specifically on those corporate activities that have detrimental consequences for the environment.

Traditionally, the protection of citizens against risk is seen as the task of states and supranational and international authorities, and an abundance of state, EU, and international regulations and control mechanisms have emerged. However, as multinational corporations and global business networks gain power, traditional checks and balances on corporate power become less effective, ${ }^{3}$ and citizens may become more vulnerable to corporate harm. At the same time, private actors - both businesses and civil society actors - have become more involved in regulation and enforcement of quality, safety, and security of goods and services. Global audit companies, labelling and certification agencies, credit rating agencies, private standards-setting authorities, accountants and NGOs are examples of private actors involved in monitoring corporations. ${ }^{4}$ Therefore, in many domains, corporate activity is regulated by a mix of public national, public international and private regulation - a mix that is sometimes smart, and sometimes suboptimal or ineffective. ${ }^{5}$ Sometimes, private actors have engaged in these roles spontaneously, to fill a gap, and sometimes their involvement is grounded in legislation. A new institutional landscape, that is more transnational and more privatised, has arisen out of the globalisation of markets, in which public national legislation and regulation have less relevance, and are supplemented, strengthened or even replaced by private social control.

\footnotetext{
${ }^{1}$ JG van Erp, W Huisman and G Vande Walle (eds), The Routledge Handbook of White-Collar and Corporate Crime in Europe (Abingdon, Routledge, 2015).

${ }^{2}$ N Passas, 'Lawful but Awful: Legal Corporate Crimes' (2005) 34 Journal of Socio-Economics 771.

${ }^{3}$ E Rich and J Moberg, Beyond Governments: Making Collective Government Work-Lessons from the Extractive Industries Transparency Initiative (Sheffield, Greenleaf Publishing, 2015).

${ }^{4}$ D Levi-Faur, "The Odyssey of the Regulatory State: From a "Thin" Monomorphic Concept to a "Thick" and Polymorphic Concept' (2013) 35 Law \& Policy 29.

${ }^{5}$ JG van Erp, M Faure, A Nollkaemper and N Philipsen (eds), Smart Mixes for Transboundary Environmental Harm (Cambridge, Cambridge University Press, 2019).
} 
A multitude of national, EU and international policy initiatives now recognise the need for the involvement of private actors in the regulation of businesses. Recently, the EU Better Regulation Guidelines, ${ }^{6}$ the OECD Regulatory Policy Outlook report (2018), ${ }^{7}$ the OECD Best Practice Principles for Regulatory Enforcement and Inspections (2014), ${ }^{8}$ and the United Nations Guiding Principles on Business and Human Rights ${ }^{9}$ all propose the stimulation of private regulation and the involvement of non-state actors and civil society in business regulation. However, it is not yet clear precisely what the role of private actors in monitoring corporations can be, in particular in a multinational context. To what extent can private actors serve as countervailing powers to corporate power? Can private social control supplement or even replace the rule of law in protecting the public interest - in other words, is it beneficial for citizens? ${ }^{10}$ Also, it still has to be determined how public regulatory bodies can make better use of the force field of private control or even stimulate it, and what this means for the organisation of public regulation and enforcement against corporate crime.

This chapter explores various roles of and opportunities for private actors to contribute to the protection of citizens against corporate environmental crime and harm, and also critically discusses potential limitations and pitfalls. As corporate environmental crime often has global implications, the chapter takes a global, rather than a European perspective. To structure the chapter, I distinguish between the roles of private actors in the detection, enforcement and regulation of corporate environmental crimes. Section 2 provides a general rationale for the involvement of private actors. Section 3 discusses the role of private actors in reporting and detecting corporate crime, and various forms in which public enforcement authorities can stimulate the receipt of information, signals and tips from private parties. Section 4 discusses the potential and pitfalls of private enforcement through extraterritorial liability litigation, and

\footnotetext{
${ }^{6}$ European Commission, 'Better Regulation: Guidelines and Toolbox' (2019) www.ec.europa.eu/info/law/lawmaking-process/planning-and-proposing-law/better-regulation-why-and-how/better-regulation-guidelines-andtoolbox_en, accessed 17 January 2019.

${ }^{7}$ OECD, OECD Regulatory Policy Outlook (Paris, OECD Publishing, 2018).

${ }^{8}$ OECD, Regulatory Enforcement and Inspections: OECD Best Practice Principles for Regulatory Policy (Paris, OECD Publishing, 2014) www.oecd.org/gov/regulatory-enforcement-and-inspections-9789264208117-en.htm, accessed 17 January 2019.

9 JG Ruggie, 'Guiding Principles on Business and Human Rights: Implementing the United Nations "Protect, Respect and Remedy” Framework' (New York and Geneva, United Nations Human Rights Council, Office of the High Commissioner for Human Rights, March 2011).

${ }^{10} \mathrm{~F}$ van Waarden and $\mathrm{K}$ van Kersbergen, 'Governance as a Bridge Between Disciplines. Cross-Disciplinary Inspiration Regarding Shifts in Governance and Problems of Governability, Accountability, and Legitimacy' (2004) 43 European Journal of Political Research 143.
} 
through reputational sanctions that come in addition to, or in the place of, legal enforcement. Section 5 discusses the regulatory capacity of private actors, its limitations and the conditions for effective public-private regulation. Section 6 summarises the argument.

\section{Why Should Private Actors Be Involved in the Protection of Citizens against Corporate Environmental Harm?}

The main reason for the increased involvement of, and attention directed towards, private actors in the regulation of corporate environmental crime and harm should be sought in the changing power balance between states and corporations in the global economy. Over the past 15 years, relations between states and markets have changed profoundly as multinational corporations have become increasingly important players in the global economy. Although various definitions exist of multinational corporations, the common ground is that a multinational corporation is a corporation that produces and/or sells products or services in more than two countries and that derives a substantial part of its revenue from operations outside its home country. These corporations are increasingly network corporations, a fact which is embodied in the concept of 'global value chains', ${ }^{11}$ referring to the entire global production process, including physical production as well as marketing, finance and sales. These processes are increasingly not carried out by one multinational corporation, but in interlinked and collaborative networks of businesses. Multinationals are therefore no longer only the large industrial producers, such as Shell or Sony. The rise of the internet economy, and the growth of the knowledge and service economy, have resulted in the emergence of smaller multinational players, and 'born global' companies which are international from the start. Multinational corporations active in European states increasingly have their roots in non-Western emerging markets, such as the Indian steel producer, Tata Steel. Financialisation has led to a more encompassing role for financial corporations and capital. Shareholder relations, private equity, hedge funds and institutional investors, as well as financial service firms which perform an important regulatory role, have become shapers of the global economy.

In all their variety, multinational corporations have gained unprecedented economic power, because of their size and scale, their flexibility to operate across the globe, and the increased

\footnotetext{
${ }^{11}$ M Timmer, 'Mondiale Waardeketens en de Nieuwe Economie' [2015] Economisch-Statische Berichten 18 December.
} 
dependence of national economies on them for employment and vital services. Through a combination of economic and regulatory power, they coordinate and control markets across borders and nation-states. ${ }^{12}$ They not only use the possibilities of globalisation, but also create new practices, networks and institutions, and therefore are seen as the primary shapers of the new institutional landscape of the global corporate economy. ${ }^{13}$ They are therefore not only an economic, but also a societal, cultural, ideological and political player. ${ }^{14}$

The increased power of global corporations brings several challenges for public regulation and enforcement to protect citizens against corporate environmental crime and harm. One of the most important tensions is that while corporate practice globalises, public regulation and enforcement institutions do not globalise at the same pace. Multinational corporations operate in regulatory gaps and can seek the most favourable regulatory regimes. ${ }^{15}$ Another problem is that traditional, nation-state-based forms of enforcement and sanctioning become less effective. Now that states increasingly depend on multinational corporations and access to global markets for economic prosperity, energy, security and capital, public supervising authorities increasingly have to weigh the importance of controlling and sanctioning corporations against economic stability, employment and national competitiveness. The balance is often struck to the benefit of maintaining good relations with corporations. Not only do many developing states exercise weak or only symbolic control of business fraud, or engage in state-corporate collusion or even corruption, but even in neoliberal states with a pro-business climate, the potential for national and local public supervising agencies to exercise meaningful control over multinational corporations and global value chains is limited. Even in most Western states, criminal prosecution of corporations is relatively rare. Despite the availability of severe administrative sanctions and the introduction of corporate criminal liability as a legal instrument in a growing number of states, in practice, a lack of enforcement capacity, the cost of sanctioning procedures and problems of proof often result in lenient or no enforcement. When imposed, sanctions are

\footnotetext{
12 P Dicken, Global Shift: Mapping the changing contours of the world economy (London, Sage, 2015).

13 J Barkan, Corporate Sovereignty: Law and Government under Capitalism (Minneapolis, University of Minnesota Press, 2013).

${ }^{14}$ S Wilks, The Political Power of the Business Corporation (Cheltenham, Edward Elgar, 2013); D Cieply, 'Beyond Public and Private: Toward a Political Theory of the Corporation' (2013) 107 American Political Science Review, 139.

${ }^{15}$ ML Djelic and S Quack, 'Institutions and Transnationalization' in R Greenwood, C Oliver, R Suddaby and K Sahlin-Andersson (eds), The Sage handbook on Organizational Institutionalism (London, Sage, 2008) 299-323; W Huisman, Business as Usual? Corporate Involvement in International Crimes (The Hague, Eleven International Publishing, 2010); Barkan (n 13); Wilks (n 14).
} 
no longer high enough to deter multinationals effectively - some multinationals have higher turnovers than the GDP of some nations. ${ }^{16}$ This has led the US author Brandon Garrett to state that large corporations are nowadays not only 'too big to fail' but also 'too big to jail'. ${ }^{17}$

From the citizens' perspective, this means that regulation, monitoring and enforcement of corporate offences by state authorities to protect them against environmental risks become less effective. But whereas the traditional role of national states as legislative, regulatory and enforcement authorities has declined, many alternatives to national state control have emerged, which are usually indicated by the term 'regulatory governance'. A wide variety of third parties can be identified that are playing or could potentially play a role in monitoring or regulating business firms. ${ }^{18}$ At the local level, local citizens and grassroots organisations can be involved in environmental protection in the case of environmentally harmful corporate activities directly affecting communities. In addition, consumers who may 'vote with their feet', consumer watchdog organisations, NGOs and interest groups, and the media, may play a role in disclosing or denouncing corporate unethical behaviour or crime. Insiders within organisations may blow the whistle when they are witnessing or even actively participating in corporate fraud. The remainder of this chapter offers a deeper and critical analysis of the involvement of private actors in the regulation and enforcement of corporate environmental crime, beginning with their role in detecting and reporting crime.

\section{Private Actors' Roles in Reporting and Detecting Corporate Environmental Harm}

The increased globalisation and technical complexity of industrial processes, in combination with diminished budgets, reduced inspection capacity, and a lack of specific expertise of

\footnotetext{
${ }^{16}$ D Korten, When Corporations Rule the World (Oakland, CA, Berrett-Koehler, 1995); N Hertz, The Silent Takeover (Portsmouth, Heinemann, 2001).

${ }^{17}$ BL Garret, Too Big to Jail. How Prosecutors Compromise with Corporations (Cambridge, MA, Harvard University Press, 2014); R Steinzor, Why Not Jail? Industrial Catastrophes, Corporate Malfeasance and Government Inaction (Cambridge, Cambridge University Press, 2015); S Will, S Handelman and DC Brotherton, How They Got Away With It: White Collar Criminals and the Financial Meltdown (New York, Columbia University Press, 2013).

${ }^{18}$ I Ayres and J Braithwaite, Responsive Regulation: Transcending the Deregulation Debate (Oxford, Oxford University Press, 1992); A Allemanno, 'Stakeholder Engagement in Regulatory Policy' in A Reader's Companion to the OECD Regulatory Policy Outlook (Paris, OECD Publishing, 2015).
} 
regulatory authorities, generate a risk that corporate environmental offences remain undetected. Therefore, the role of private parties in detecting, reporting and disclosing corporate offences is of increasing importance. Employees, customers, competitors, collaborators and inhabitants of local communities maintain relations with corporations that enable them to witness environmental offences. The knowledge obtained by these insiders or close outsiders can be very valuable for the detection work of public inspectorates. This section discusses three categories of external reporting of corporate environmental crime: whistleblowing, bell-ringing and anonymous reporting through digital platforms.

\subsection{Whistleblowing}

Whistleblowers are members (or former members) of an organisation in which offending behaviour takes place, who report this offence to an authority within or outside the organisation. Although whistleblowers can voice their concern internally within the organisation, their reports, tips and signals can also be highly valuable to public inspectorates and enforcement authorities, as offences are often difficult to detect from the outside, in particular against the background of diminishing budgets for detection activities and the growing complexity of business processes and markets.

However, whistleblowers are also confronted with serious obstacles. They are likely to lose their occupation and encounter difficulties in finding new employment, and also face the risk of social exclusion and retaliation by former colleagues or their professional community. Whistleblower protection laws and institutions are therefore important to stimulate reporting and safeguard whistleblowers against retaliation. Most European countries now have whistleblowing protection laws, covering both the public and private sector. Several countries have established dedicated agencies to receive and investigate reports and provide legal, financial and psychosocial support to whistleblowers, ${ }^{19}$ or countries may subsidise NGOs to perform these tasks. However, significant variation exists between countries in the EU in the protection offered and support provided to whistleblowers. The European Commission proposed an EU-wide directive in April 2018 to provide more uniform protection. ${ }^{20}$ Although

\footnotetext{
${ }^{19}$ K Loyens and W Vandekerckhove, 'Whistleblowing from an International Perspective: A Comparative Analysis of Institutional Arrangements’ (2018) 8 Administrative Sciences 30.

${ }^{20}$ Proposal for a Directive of the European Parliament and of the Council on the protection of persons reporting on breaches of Union law $(\operatorname{SWD}(2018)$ 116-17 final), Brussels, 23 April 2018, https://ec.europa.eu/info/law/better-regulation/initiatives/com-2018-218_en, accessed 17 January 2019.
} 
this may help to stimulate whistleblowing, the NGO Transparency International has argued that the proposed directive still leaves several problems unaddressed, such as the desire for anonymity, confidentiality and financial compensation for whistleblowers. ${ }^{21}$ The EU's approach is also in contrast with much more far-reaching legislation in the United States, which has introduced rewards for whistleblowers. The Dodd-Frank Act entitles whistleblowers to between 10 and 30 per cent of the recuperated funds, in cases where the investigation initiated by the report results in a fine of US\$1 million or more. Similar rewards are available under the US False Claims Act 2010.22

\subsection{Bell-ringing}

The hurdles that whistleblowers face as reporters of corporate criminal or harmful activities focus attention on the potential of external reporters, such as parties who maintain a professional relationship with the (supposedly) offending organisation and witness offences during contacts with the offender. The term 'bell-ringers' has been suggested for this category, to distinguish them from whistleblowers who are insiders. ${ }^{23}$ Bell-ringers may possess information about offences that may equal information from whistleblowers, but they are less likely to face negative consequences from reporting, and may therefore be more willing to report. They can therefore be a particularly valuable source of information for public inspectorates. For example, the Volkswagen diesel fraud was reported to the Environmental Protection Agency by the University of West Virginia's Research Centre for Alternative Fuels, Engines and Emissions. ${ }^{24}$ Whereas public authorities only inspected diesel emissions in the laboratory, a research project by these academic investigators also measured emissions on the road, and detected a discrepancy between the laboratory and road test results.

\footnotetext{
${ }^{21}$ Transparency International, 'Whistleblower Protection in the EU: Analysis of and Recommendations on the Proposed EU Directive’ (2018) Transparency International, Berlin, Position Paper 1.

${ }^{22}$ D Lewis, T Devine and P Harpur, 'The Key to Protection: Civil and Employment Law Remedies' in AJ Brown, D Lewis, RE Moberly and W Vandekerckhove (eds), International Handbook on Whistleblowing Research (Cheltenham, Edward Elgar, 2014) 350-80.

${ }^{23}$ MP Miceli, S Dreyfus and JP Near, 'Outsider "Whistleblowers": Conceptualizing and Distinguishing "Bellringing” Behavior' in AJ Brown, D Lewis, R Moberly and W Vandekerckhove (eds), International Handbook on Whistleblowing Research (Cheltenham, Edward Elgar, 2014) 71-94; JG van Erp and K Loyens, 'Why External Witnesses Report Organizational Misconduct to Inspectorates: A Comparative Case Study in Three Inspectorates' [2018] Administration \& Society July 14.

${ }^{24}$ G Thompson, D Carder, C Besch, A Thiruvengadam and H Kappanna, 'In-Use Emissions Testing of Light-Duty Diesel Vehicles in the United States' (2014) Center for Alternative Fuels, Engines \& Emissions, West Virginia University, Morgantown.
} 
There are also examples of environmental NGOs that actively collect data on (supposed) environmental offences and report them, such as the Blackfish Foundation, a 'citizen inspection network' that trains volunteers to monitor illegal overfishing in European ports. These citizen inspectors visit ports and sometimes also carry out coastal or air patrols to observe poaching of illegal fish species, illegal bycatch or catch of too small and young fish, and to monitor mesh sizes and use of illegal nets such as drift-nets. They gather evidence and present it to local and international authorities to stimulate more stringent enforcement and prosecution. ${ }^{25}$ Such NGOs can be particularly useful for monitoring compliance in countries where state inspection and enforcement capacity is limited (such as with overfishing) or when enforcement is captured. An example of an NGO that supplements public enforcement is Global Witness, which specialises in undercover investigations to gather evidence and expose illegal exploitation of natural resources in the oil, gas, minerals and timber industries in developing economies. ${ }^{26}$

To receive information from private actors, many inspectorates actively solicit tips, suspicions and complaints from external parties, often through specialised web portals and complaints centres. Examples of these include the British Food Standards Agency reporting website and the website of the EU Anti-Fraud Office, OLAF. ${ }^{27}$ Technology can be employed to facilitate the reporting process. In the Netherlands, the health and safety inspectorate has developed an asbestos app for reports of the illegal and unlicensed removal of asbestos. Professional asbestos removal companies, which frequently observe unlicensed removal by less professional competitors, use this app to report these incidents to the inspectorate. ${ }^{28}$

Opening up inspection processes to signals and reports by outsiders may challenge standard operational processes of public enforcement agencies in various ways. They may be faced with a multitude of reports which they cannot handle, or with reports that are so serious that a timeconsuming investigation is required for which no capacity is available. Worse, reports can uncover incidents that have been undetected or ignored by the authorities and may compromise authorities, or jeopardise existing state-corporate relations, which may make authorities less

\footnotetext{
${ }^{25}$ The Black Fish, 'Our Story' (White Fuse, 2018) www.theblackfish.org/pages/6-our-story, accessed 17 January 2019.

${ }^{26}$ Global Witness, 'How We Work” (Global Witness, 2018) www.globalwitness.org/en/, accessed 17 January 2019.

27 Food Standards Agency, 'About Us' (FSA, UK, 2018) www.food.gov.uk/enforcement/enforcework/report, accessed 17 January 2019; European Anti-Fraud Office, 'Report Fraud' (European Commission, 2018) ec.europa.eu/anti-fraud/olaf-and-you/report-fraud_en, accessed 17 January 2019.
}

${ }^{28}$ Van Erp and Loyens (n 23). 
willing to follow up on reports. ${ }^{29}$ These insights reveal that detection is not only a matter of organisation and technology, but also a political process, and that the success of governmentinvited tips and complaints partly depends on the responsiveness of public authorities to their environment. ${ }^{30}$ In particular, in countries with close relations between states and corporations, information from private reporters may therefore be unwelcome, as recently became evident when the Democratic Republic of the Congo (DRC) detained and expelled two members of Global Witness, who were legally visiting the DRC to monitor the compliance of logging companies with DRC national legislation. ${ }^{31}$

In addition, outsiders, such as members of organisations with a professional relationship with a corporation, can play a monitoring or regulatory role, such as business clients or suppliers which collaborate in supply chains. Competitors as well as business sector organisations may report fraud when they suspect it, in the interests of a level playing-field and the good reputation of the business sector. Institutional investors, such as banks and pension funds, increasingly monitor the ethical aspects of the business activities they invest in. For insurance companies, there is a direct financial interest in preventing corporate activities with negative external effects, as they often will be responsible for paying damages. Finally, professional monitoring and auditing firms, such as certification bodies, accountants, tax auditors, legal advisors and consultants, responsible for private control and fraud prevention of businesses, may play a public monitoring or regulatory role as well. Increasingly, these parties have reporting duties when they observe or suspect fraud or otherwise observe signals of unusual activities. Even without these legal duties, however, they can be made more aware of their social responsibility to report suspect business activities voluntarily.

\subsection{Digital Reporting Platforms}

In the light of the ambivalent reactions to whistleblowers and bell-ringers by state authorities and by professional and social communities, it should come as no surprise that alternative initiatives have developed for the disclosure of corporate malpractice, independent of state authorities. Most importantly, and again facilitated by technology, the various internet

\footnotetext{
${ }^{29} \mathrm{~N}$ Reichman, 'Getting Our Attention' (2014) 9 Criminology \& Public Policy 483; J Etienne, 'The Politics of Detection in Business Regulation' (2014) 25 Journal of Public Administration and Theory 257.

${ }^{30} \mathrm{H}$ van de Bunt, 'Walls of Secrecy and Silence: The Madoff Case and Cartels in the Construction Industry' (2010)

9 Criminology \& Public Policy 435

${ }^{31}$ Global Witness, 'Global Witness Employees Expelled from DRC under False Allegations' (press release, 14 July 2016).
} 
platforms for anonymous reporting can be considered game-changers in the way in which states and citizens interact. The International Consortium of Investigative Journalists (ICIJ) hosts an encrypted SecureDrop server to allow whistleblowers to leak documents while completely protecting their identity. Its aim is to uncover 'important government and corporate activities that might otherwise go unreported'. ${ }^{32}$ In the area of corporate environmental crime, the ICIJ has uncovered environmentally harmful practices and rule-breaking by Australian mining corporations in 13 African countries including toxic releases in rivers by gold and uranium mining companies. ${ }^{33}$ The strength of these reporting platforms is not only that they are more attractive for whistleblowers and bell-ringers than reporting to public authorities because they limit the risk of self-incrimination or loss of anonymity, but also because they are global in scale and encourage the uncovering of harmful or unethical practices at the state-corporate nexus.

\section{Extraterritorial Enforcement through Liability Claims or Extralegal Sanctions}

Corporations, as profit-maximising entities, generally need an incentive to comply with regulation in the public interest. Public enforcement and sanctioning by state authorities traditionally provides the 'shadow of hierarchy' that is a necessary condition for (more or less voluntary) compliance by corporations. Earlier in this chapter, I outlined a variety of reasons why the impact of public sanctions and state enforcement is becoming less effective against multinational corporations. To summarise: production facilities are often located in states with a friendly attitude towards multinational corporations because of less stringent legislation; and some public enforcement agencies have limited enforcement capacity and expertise, and the state greatly depends on the presence of multinational corporations - either through corruption or implicitly through economic dependency. Moreover, globalisation increases the possibility for businesses to find legal loopholes for circumventing the law. When economic sanctions are imposed, they often have a limited deterrent effect against the economic power of corporations,

\footnotetext{
32 International Consortium of Investigative Journalists, 'Leak to Us' (ICIJ, 2018) www.icij.org/securedrop, accessed 17 January 2019.

${ }^{33}$ W Fitzgibbon, 'Investigation Reveals “Environmental Ruin” and Workers Rights Abuses' (16 July 2015) International Consortium of Investigative Journalists, www.icij.org/investigations/fatal-extraction/investigationreveals-environmental-ruin-and-workers-rights-abuses/, accessed 17 January 2019.
} 
and also can often be successfully resisted through appeal procedures. To sum up, the 'shadow of hierarchy' that serves as a big stick to stimulate firms to comply with regulations is often lacking in global settings, leaving citizens more vulnerable to risk.

The weakening impact of public sanctions increases the need to find alternatives to public enforcement. The threat of extralegal punishment, such as negative publicity, reputational sanctions, shareholder pressure or supply chain sanctions sometimes deters and prevents business fraud more powerfully than legal sanctions. These alternative strategies could be particularly powerful in globalised markets. In the absence of a shadow of hierarchy provided by the nation-state, globalisation enables the emergence of functional equivalents for state legislation and enforcement. ${ }^{34}$ This section discusses two of these equivalents: extraterritorial legal enforcement and reputational sanctions.

\subsection{Extraterritorial Law Enforcement}

Laws with extraterritorial application extend their reach outside the state's territory by holding corporations responsible for their acts across their global supply chains. Such liability can be civil, criminal or administrative. France has recently adopted legislation introducing a duty of care for parent and subcontracting companies. ${ }^{35}$ Under these laws, victims of environmental harm inflicted by irresponsible corporate behaviour can bring civil actions before the French courts. Similar legislative proposals are being developed in Switzerland by the Swiss Responsible Business Initiative. Criminal liability enables states to prosecute firms for violations overseas. In Europe, prosecutors usually exercise this authority over foreign bribery. In the United States, the US Alien Torts Claims Act is the most powerful example of such an Act, granting jurisdiction to US federal courts over any claim arising out of the violation of US national or international law anywhere in the world, including corporate human rights violations and environmental crime, under the condition that these violations are somehow related to US territory - a condition currently under debate. Administrative extraterritorial enforcement is an

\footnotetext{
${ }^{34}$ TA Börzel and T Risse, 'Governance without a State: Can it Work?' (2010) 4 Regulation \& Governance 113; TA Börzel and T Risse, 'Dysfunctional State Institutions, Trust, and Governance in Areas of Limited Statehood' (2016) 10 Regulation \& Governance 149.

${ }^{35}$ Loi relative au devoir de vigilance des sociétés mères et des entreprises donneuses d'ordre: see S Cossart, J Chaplier and T Beau de Lomenie, 'The French Law on Duty of Care: A Historic Step Towards Making Globalization Work for All' (2017) 2 Business and Human Rights Journal 317.
} 
option in the EU Timber Regulation which aims to ban the import of illegally harvested timber ${ }^{36}$ and the EU Conflict Minerals Regulation which obliges mining corporations to use only responsibly sourced minerals. ${ }^{37}$

The actual impact of these laws obviously depends on the willingness and capacity of state authorities to enforce and the actual access to justice of victims. Here, private parties such as international NGOs or specialised international human rights litigation firms can act on behalf of victims claiming damages. For example, the Ivorian victims of the dumping of toxic waste by the ship Probo Koala, operated by commodity trader Trafigura, are currently claiming damages in a liability procedure in an Amsterdam court. Although Trafigura is a French company, its legal seat is in the Netherlands. ${ }^{38}$ This example of Ivorian victims claiming damages in a Dutch court against a French company vividly illustrates how globalisation offers opportunities to use a very traditional legal instrument, liability procedure, for control of global corporations. ${ }^{39}$ But again it should be realised that the impact of these claims in the light of the massive damage caused by corporations is very limited. Liability procedure has many practical obstacles for victims, because it requires access to investigatory and legal resources beyond the reach of most individuals and because of the difficulties of burden of proof. ${ }^{40}$ Even when claims are granted, enforcement problems exist: an earlier claim against Trafigura, even though it was granted, never resulted in compensation for some victims, because a fraudulent claim against the funds was made and was upheld in the Ivorian Supreme Court. In this case, ironically, the firm that aimed to defend the rights of victims of transnational environmental harm was found guilty of neglecting these rights, and the legal avenues available for claiming compensation for

\footnotetext{
${ }^{36}$ The 2013 Timber Regulation: Regulation (EU) No 995/2010 of the European Parliament and of the Council of 20 October 2010 laying down the obligations of operators who place timber and timber products on the market. Brussels, European Commission, 2010, 1-12.

${ }^{37}$ European Commission, Proposal for a Regulation of the European Parliament and of the Council: setting up a Union system for supply chain due diligence self-certification of responsible importers of tin, tantalum and tungsten, their ores, and gold originating in conflict-affected and high-risk areas (COM/2014/0111 final 2014/0059 (COD)).

${ }^{38} \mathrm{CG}$ van Wingerde, 'The Limits of Environmental Regulation in a Globalized Economy: Lessons from the Probo Koala case' in JG van Erp and W Huisman (eds), Routledge Handbook of White-Collar and Corporate Crime in Europe (Abingdon, Routledge, 2015).

${ }^{39}$ L Enneking, 'The Future of Foreign Direct Liability? Exploring the International Relevance of the Dutch Shell Nigeria Case' (2014) 10 Utrecht Law Review 44; also see Börzel and Risse (n 34, 2010, 2016).

${ }^{40}$ L Enneking, F Kristen, K Pijl, T Waterbolk, J Emaus, M Hiel, A-J Schaap and I Giesen, Zorgplichten van Nederlandse ondernemingen inzake internationaal maatschappelijk verantwoord ondernemen. Een rechtsvergelijkend en empirisch onderzoek naar de stand van het Nederlands recht in het licht van de UN Guiding Principles (Den Haag, Boom Juridische Uitgevers, 2016); M Hall, Victims of Environmental Harm: Rights, Recognition and Redress under National and International Law (London, Routledge, 2013).
} 
victims were used against victims. In other words, although extraterritorial enforcement is viewed as an alternative for the 'shadow of the state', the outcomes are often unpredictable to say the least.

Much more than direct compensation for victims therefore, international human rights liability procedures might have an impact through their deterrent effect on multinational corporations. Here, the fear that a lawsuit against a multinational corporation in a home country, often accompanied by a fair amount of publicity sympathetic to the victim, will negatively impact the reputation of a multinational corporation may be an important factor, even regardless of the outcome of the lawsuit. The next section discusses the impact of such 'reputational sanctions' in more detail.

\subsection{Reputational Sanctions}

The threat of reputational damage is often considered as a strong deterrent that can reinforce, complement or even replace legal sanctions to the extent that scholars speak about 'reputational sanctions'. ${ }^{41}$ In addition to the external shadow of hierarchy that is invoked by the threat of public or private enforcement in foreign states, Börzel and Risse ${ }^{42}$ distinguish a second form of social control enabled by globalisation: the shadow of the foreign market. The foreign market can cast a shadow when buyers in home markets react to human rights infringements by multinational corporations in producing countries. In other words, firms that violate human rights or environmental standards, even when they concern social rather than legal norms, face a competitive disadvantage. As a result, the environmental and human rights standards that have developed in the Global North are translated into the Global South. This process is triggered by active publicity campaigns and naming and shaming by environmental or human rights NGOs. International NGOs assisting victims of corporate environmental harm in activating their rights strategically select cases that can be expected to have an impact on public opinion and eventually result in more stringent legislation, or that will pressurise multinational corporations to change their practices to avoid negative publicity. Although these campaigns rarely result in actual consumer boycotts or significant drops in sales, research suggests that the threat of reputational damage may have an independent effect by alerting stakeholders, employees,

\footnotetext{
${ }^{41}$ EM Iacobucci, 'On the Interaction between Legal and Reputational Sanctions' (2013) 43 Journal of Legal Studies 189; R Brewster, 'Pricing Compliance: When Formal Remedies Displace Reputational Sanctions' (2013) 54 Harvard International Law Journal 259.
}

${ }^{42}$ Börzel and Risse (n 34, 2010, 2016). 
unions, shareholders and the media, and thus generate more indirect pressure on multinationals to adapt their own production processes or to place their subcontractors under closer scrutiny. ${ }^{43}$ 'Naming and shaming' becomes an even more powerful tool now that the internet and social media allow citizens and NGOs to publicise corporate harmful behaviour at unprecedented speed and levels of exposure. More than ever before, local problems can be made visible on a global scale. $^{44}$

In addition to citizens and NGOs naming and shaming businesses which damage the environment or human rights in developing states, governments in the Global North may stimulate the process of reputational pressure, by legally requiring transparency of businesses on their human rights policies, or the disclosure of information about compliance, inspections or enforcement against businesses, including their names. The availability of information about the corporate social responsibility (CSR) of businesses is an important condition for the effectiveness of reputational regulation, and rather than directly intervening in business processes, legislation may stimulate the disclosure of this information to the market. A European example is the recently introduced EU Directive that requires large companies to include a statement in their annual report about their policies for the protection of the environment, human rights, employee rights, and anticorruption and bribery policies. ${ }^{45}$ This 'comply or explain' policy will not only expose to shareholders and stakeholders which companies devote less attention to CSR, but can also serve as a benchmark to educate firms about each other's CSR policies and thus stimulate a 'race to the top'. ${ }^{46}$ Such disclosure may actually be more preventative than ex post naming and shaming as it stimulates all businesses to improve their policies, rather than only those that have offended. Scholars have observed a 'transparency turn', particularly in environmental governance, ${ }^{47}$ with a wide range of forms of

\footnotetext{
${ }^{43}$ JG van Erp, 'Messy Business: Media Representations of Administrative Sanctions for Corporate Offenders' (2013) 35 Law \& Policy 109.

${ }^{44}$ Rich and Moberg (n 3).

${ }^{45}$ Directive of the European Parliament and the Council amending Directive 2013/34/EU as regards disclosure of non-financial and diversity information by certain large undertakings and groups; PE-CONS 47/14; July 2014. http://register.consilium.europa.eu/doc/srv?l=EN\&f=PE\%2047\%202014\%20INIT, accessed 17 January 2019. This Directive requires certain large business enterprises to report on their policies relating to the environment, social and personnel issues, human rights and the combat of corruption and bribery.

${ }^{46}$ JG van Erp, 'Naming Without Shaming: The Publication of Sanctions in the Dutch Financial Market' (2011) 5 Regulation \& Governance 287.

${ }^{47}$ A Gupta and M Mason, 'A Transparancy Turn in Global Environmental Governance' in A Gupta and M Mason (eds), Transparency in Global Environmental Governance: Critical Perspectives (Cambridge, MA, MIT Press, 2014) 3-38.
} 
disclosure of information from state to the public, state to state, corporations to the public, and corporations to states; and both mandatory and voluntary disclosure. Klein and Moberg, basing themselves on the Extractive Industries Transparency Initiative, which stimulates disclosure of revenue payments from mining corporations in mining countries, have experienced the fact that disclosure has moved from just providing data, into making businesses more accountable by data, by using data in a meaningful way. ${ }^{48}$ However, although transparency opens up space for forms of control by private actors, there is of course no guarantee that actual control takes place or that corporations will be sensitive to this control. ${ }^{49}$ The diminishing deterrent impact of national legal enforcement creates an extra need for the development of a better understanding of the exact conditions and mechanisms through which the threat of reputational damage results in actual change of behaviour, rather than in just window-dressing.

\section{Private Regulation}

Neoliberal markets are often associated with deregulation and a lack of control, but this is a misunderstanding of the type of control that is exercised in modern markets. Contemporary markets, and particularly global markets, are thoroughly regulated, but only part of this regulation stems from the state: the majority of regulatory activity is undertaken by private regulatory services. ${ }^{50}$ The British lawyer, Julia Black states: 'If "regulation” remains a concept tied inherently to the state, then in trying to analyse it, we will find contemporary forms of rule hard to understand, if indeed, we recognise them at all. ${ }^{51}$ Private regulatory activities can consist of the development of rules and 'soft law' such as codes of conduct, standards, contracts and labels, and of monitoring adherence to these rules, as is done by certifying agencies, accountants, credit rating agencies, ${ }^{52}$ insurance agents and NGOs. These forms of private regulation can exist in alliance with national legislation, as a form of implementation, or in addition to national legislation to induce 'beyond compliance' behaviour.

\footnotetext{
${ }^{48}$ Rich and Moberg (n 3).

${ }^{49}$ van Erp (n 43); Gupta and Mason (n 47); van Wingerde (n 38).

${ }^{50} \mathrm{~J}$ Braithwaite and P Drahos, Global Business Regulation (Cambridge, Cambridge University Press, 2000)

${ }^{51}$ J Black, 'Critical Reflections on Regulation' (2002) 27 Australian Journal of Legal Philosophy, 17; C Scott, F Cafaggi and LAJ Senden, The Challenge of Transnational Private Regulation: Conceptual and Constitutional Debates (Hoboken, NJ, Wiley-Blackwell, 2011).

${ }^{52}$ A Naciri, Credit Rating Governance: Global Credit Gatekeepers (Abingdon, Routledge, 2015).
} 
Private regulation has several strengths compared with public regulation. First, private regulators operate beyond national borders, often at the international level, to implement international norms. This gives them a better position than public regulators to play a meaningful role in globalised markets and transnational value chains, which is particularly relevant for environmental crime, as its harmful effects often cross borders. Second, private regulation allows the taking of advantage of industry expertise to design arrangements that fit the context and complexity of industrial processes, in particular new technologies with new environmental effects. For example, the covenant between the Dutch government and offshore oil industry for offshore drilling sets standards for environmentally conscious drilling and waste reduction that are agreed between the government and the industry. Each company operating on the Dutch continental shelf is obliged to develop a Company Environmental Plan, which requires approval from the Ministry of Economic Affairs. The aggregate of plans form an Industry Environmental Plan, which evaluates the total results of all the individual plans against the agreed objectives of the environmental covenant. Technical expertise is exchanged in working groups for specific issues, such as waste management, or emissions. In addition to environmental standards being better suited to the specific context, and compliance being more voluntary, the covenant allows for more integrated prevention of soil, air and water pollution than the public regulation that existed before. ${ }^{53}$ Third, corporations have an incentive for compliance with private standards because adherence often generates a competitive advantage. ${ }^{54}$ For example, 'green' labelling distinguishes goods that are produced in an environmentally conscious way from other goods, and such labelling may attract customers and incentivise companies to comply voluntarily. Finally, private regulation can operate much faster than state legislation, and is therefore better able to keep up with innovation and technological development. ${ }^{55}$ All in all, private regulation can thus overcome some of the shortcomings of public regulation in global markets.

The increasing importance of private regulators in the global economy should also raise awareness, however, of incidents in which private regulation has proven ineffective in preventing large corporate scandals, or has even served simply as window-dressing. The

\footnotetext{
53 J Van Tatenhove, 'Regulatory Mixes in Offshore Oil Production: Are they Smart?' in van Erp et al (n 5).

${ }^{54} \mathrm{H}$ van der Ven, 'Correlates of Rigorous and Credible Transnational Governance: A Cross-Sectoral Analysis of Best Practice Compliance in Eco-labeling' (2015) 9 Regulation \& Governance 276.

${ }^{55}$ K Abbott, 'Introduction: The Challenges of Oversight for Emerging Technologies' in G Marchant, K Abbott and B Allenby (eds), Innovative Governance Models for Emerging Technologies (Cheltenham, Edward Elgar, 2013).
} 
Volkswagen diesel fraud provides a powerful example. In the European car industry, diesel emissions are approved based on test certificates of private auditing companies. Although road tests are to a certain extent standardised on the basis of the New European Driving Cycle, private auditing companies vary regarding the intensity of testing, and circumstances vary across test circuits. Car manufacturers strategically select test agencies to their advantage. ${ }^{56}$ Volkswagen was also ranked very positively by reputation-ranking agencies for sustainability and CSR performance. ${ }^{57}$

This raises important questions about the actual monitoring and enforcement of private norms, as carried out by private regulators, and the conditions under which conformity to private regulation is meaningful or under which it remains no more than a ritual. The European Environmental Agency has already expressed concern that it is not possible to assess the actual functioning of verification processes in practice. ${ }^{58}$ One of the trade-offs with private regulation is that it involves industry and experts more closely in the regulatory process, but it may be less transparent and democratically accountable, and more closed off from environmental groups, the media or other critical observers of industry. According to the Aarhus Convention on access to information, public participation and access to justice, citizens and environmental NGOs have a right to information. ${ }^{59}$ However, various European regulations with regard to environmental issues, such as regulation of biofuels and maritime emissions, outsource certification and verification processes to private parties. ${ }^{60}$ As the Aarhus Convention applies to governmental information, the right to information does not automatically extend to these private certifying and verifying parties. ${ }^{61}$ Requests for information about verification of industrial emissions by environmental NGOs may be refused, for example on the basis of

\footnotetext{
${ }^{56}$ M Nesbit, N Ferguson, A Colsa, J Ohlendorf, C Hayes, K Paquel and J Schweitzer, 'Comparative Study on the Differences Between the EU and US Legislation on Emissions in the Automotive Sector' (2016) Study for the European Parliament Directorate General for Internal Policies, IP/A/EMIS/2016-02, PE 587, 331.

${ }^{57}$ Ranking the Brands, 'Rankings per Brand: VW (Volkswagen)' (2018) www.rankingthebrands.com/Branddetail.aspx?brandID=189, accessed 17 January 2019.

${ }^{58}$ European Environment Agency, Application of the EU Emissions Trading Scheme Directive - Analysis of National Responses under Article 21 of the EU ETS Directive in 2015 (Luxembourg, Publications Office of the European Union, 2016); see also M Peeters and M Müller, 'Private Control of Public Regulation: A Smart Mix? The Case of Greenhouse Gas Emission Reductions in the EU' in van Erp et al (n 5).

${ }^{59}$ Directive 2003/4/EC of the European Parliament and of the Council of 28 January 2003 on public access to environmental information (Aarhus Convention).

${ }^{60}$ Regulation (EU) 2015/757 of the European Parliament and of the Council of 29 April 2015 on the monitoring, reporting and verification of carbon dioxide emissions from maritime transport, and amending Directive 2009/16/EC OJ L 123/55; Directive 2009/28/EC of the European Parliament and of the Council of 23 April 2009 on the promotion of the use of energy from renewable sources; see also Peeters and Müller (n 58).

${ }^{61}$ Peeters and Müller (n 58).
} 
business confidentiality. The involvement of private parties in the regulation of emissions and biofuels is therefore only partial, as environmental NGOs working in the public interest, and individual citizens, are closed off from the regulatory process or at least kept at a large distance.

Recent new governance literature increasingly addresses limitations of private regulation and public-private regulatory arrangements such as those described above. ${ }^{62}$ Authors argue that private regulation is flexible and pragmatic, but that can also lead to 'satisficing' rather than optimal outcomes in terms of the public interest. ${ }^{63}$ Authors have also noted that states sometimes embrace private regulation in the face of budget cuts to enforcement, which raises the question whether private regulation is better, or just cheaper. ${ }^{64}$ The new governance literature idealistically states that the state's power has not been reduced, but has simply been redistributed. ${ }^{65}$ However, it is important to empirically investigate the question whether private regulation in the end entails different or maybe just less stringent regulation.

Recent research conducted on this topic has compared the effectiveness of a number of private regulation arrangements, such as codes of conduct and standards, and concludes that these only lead to behavioural change in a powerful legal environment. Companies adhere to voluntary private standards when they are embedded in states that have stringent domestic labour laws, actively participate in the International Labour Organization, and have high levels of press freedom. ${ }^{66}$ It has therefore become increasingly clear that effective private regulation also depends on a strong public enforcement apparatus because, when there is no realistic enforcement, commitment to codes is often just symbolic. ${ }^{67}$ In other words, private regulation is most effective when it is backed up, or supported, by public regulation. A good example is

\footnotetext{
${ }^{62}$ P Almond, 'Revolution Blues: The Reconstruction of Health and Safety Law as "Common-Sense" Regulation' (2015) 42 Journal of Law and Society 202; J Black, 'Paradoxes and Failures: "New Governance” Techniques and the Financial Crisis' (2012) 75 MLR 1037; DM Curtin and LAJ Senden, 'Public Accountability of Transnational Private Regulation: Chimera or Reality?' (2011) 38 Journal of Law and Society 163.

${ }^{63}$ C Ford, 'New Governance in the Teeth of Human Frailty: Lessons from Financial Regulation' [2010] Wisconsin Law Review 441.

${ }^{64}$ RW Mills and CJ Koliba, 'The Challenge of Accountability in Complex Regulatory Networks: The Case of the Deepwater Horizon Oil Spill' (2015) 9 Regulation \& Governance 77.

${ }^{65}$ Wilks (n 14); cf Levi-Faur (n 4); Djelic and Quack (n 15).

${ }^{66}$ MW Toffel, JL Short and M Ouellet, 'Codes in Context: How States, Markets, and Civil Society Shape Adherence to Global Labor Standards' (2015) 9 Regulation \& Governance 205; JL Short and MW Toffel, 'Making Self-Regulation More Than Merely Symbolic: The Critical Role of the Legal Environment' (2010) 55 Administrative Science Quarterly 361; G Distelhorst, RM Locke, T Pal and H Samel, 'Production Goes Global, Compliance Stays Local: Private Regulation in the Global Electronics Industry' (2015) 9 Regulation \& Governance 224.

${ }^{67}$ van Erp et al (n 5).
} 
the EU 2003 Forest Law Enforcement, Governance and Trade Action Plan, which aims to eliminate imports of illegally produced timber into the EU by requiring licensing of wood products before they are allowed to be imported in the EU. ${ }^{68}$ Balleisen and Eisner conclude that five factors are particularly important to the effectiveness of regulatory frameworks that combine government oversight with industry self-policing: (i) the depth of concern for their reputation among regulated businesses; (ii) the relevance of flexibility in regulatory detail; (iii) the existence of sufficient bureaucratic capacity and autonomy on the part of non-governmental regulators; (iv) the degree of transparency in regulatory process; and (v) the seriousness of accountability. ${ }^{69}$

\section{Final Remarks}

The activities of corporations can have harmful effects on the environment, damaging the health and welfare of citizens in the shorter and longer term. Whereas environmental protection was for a long time the legal responsibility of states, private actors are now prominent on the regulatory stage. Multinational corporations, financial institutions and civil society organisations have emerged as sources of global power. Private control institutions, such as transnational private regulatory bodies, private monitoring, audit and rating agencies, NGOs, the media and financial institutions, are now supplementing, replacing or overtaking public regulation. Citizens can contribute to global enforcement by participating in online "naming and shaming' campaigns. Regulatory authority is no longer the monopoly of the state, but corporate and state-corporate interactions take place in horizontal and global networks that can be pluralistic and diversified, but can just as well be fragmented and uncoordinated. For citizens, this means that new and more dispersed opportunities for prevention of harmful and criminal corporate activities arise, but the question as to the effectiveness of these opportunities in protecting citizens and the environment is difficult to answer in general terms. Some authors have argued that the 'holllowing out of the state' has resulted in a new corporate world order in

\footnotetext{
${ }^{68}$ European Commission, 'Forest Law Enforcement, Governance and Trade (FLEGT): Proposal for an EU Action Plan' (COM(2003) 251 final).

${ }^{69}$ EJ Balleisen and M Eisner 'The Promise and Pitfalls of Co-Regulation: How Governments Can Draw on Private Governance for Public Purpose' in D Moss and J Cisternino (eds), New Perspectives on Regulation (Cambridge, The Tobin Project, 2009) 127-49.
} 
which multinationals are too big to fail and too big to jail; and public and private enforcement are powerless and captured. Other authors are more optimistic and argue that the shadow of hierarchy' has been replaced by a web of liability. The reality, of course, varies from case to case.

In this chapter, I have given several examples of how globalisation, growing interconnectedness and the worldwide flow of information not only strengthen the position of multinationals, but also enable new control institutions to emerge. I have discussed various roles of private actors in detecting, enforcing and regulating corporate environmental crime and harm. The operation of businesses on a global scale creates opportunities for global enforcement; both formal legal enforcement by private actors and informal enforcement through transparency and reputational sanctions. Extralegal penalties may partly solve the enforcement gap that arises out of the weakening position of nation-states. Technology and new media can assist the reporting and disclosure of corporate harmful behaviour and environmental damage in places that are remote and inaccessible to the general public. And the global nature of business creates the need for standardisation and regulation of corporate activity by private bodies, resulting in soft forms of oversight such as codes of conduct, rankings and certification. The examples in this chapter certainly show that private actors can be a source of prevention of corporate fraud and harm, although their impact can still be much improved. In response to the calls from the EU and OECD for more involvement of private stakeholders in regulation, this chapter has demonstrated that many opportunities exist that can still be further explored and developed, in the areas of detection, enforcement and regulation of corporate behaviour.

This chapter has also demonstrated that private actors sometimes lack strength, in some cases have no more than symbolic roles and do not always live up to expectations. This chapter teaches that a critical assessment is necessary of the real possibilities and capacities of private actors. In the case of the diesel emissions fraud, for example, the private monitoring of emissions by certification agencies often appears to be only symbolic scrutiny. And state enforcement authorities should maintain a healthy suspicion with regard to the activities of private regulators, especially when these private regulators face perverse incentives to be less critical.

One of the lessons of the analysis in this chapter is that what works is often a combination of legislation and public law enforcement, and private regulation and control. In many cases, private actors operate separately from public monitoring and enforcement, which leaves potential unused. Detection and reporting by whistleblowers or bell-ringers, for example, is 
most effective when tips and signals are followed up by public enforcement. Civil liability cases can only be effective when legal grounds exist for holding parent corporations to account for activities in subsidiaries. Among policy-makers, realisation is growing that non-binding, regulatory mechanisms alone may not be sufficient to prevent corporate harmful behaviour. In 2011, the European Commission had already moved away from its definition of CSR as a purely voluntary concept, stating that '[c]ertain regulatory measures create an environment more conducive to enterprises voluntarily meeting their social responsibility'. ${ }^{70}$

To conclude, involvement of private actors in the enforcement of corporate environmental crime requires public regulators to rethink how their relationship with private actors can be shaped to realise an optimal mix of regulatory power to protect citizens from harmful corporate acts.

\footnotetext{
${ }^{70}$ European Commission, ‘A Renewed EU Strategy 2011-14 for Corporate Social Responsibility’ (COM(2011) 681 final).
} 